This item is the archived peer-reviewed author-version of:

Which cues cause consumers to perceive brands as more global? A conjoint analysis

\title{
Reference:
}

De Meulenaer Sarah, Dens Nathalie, De Pelsmacker Patrick.- Which cues cause consumers to perceive brands as more global? A conjoint analysis

International marketing review - ISSN 0265-1335 - 32:6(2015), p. 606-626

Full text (Publishers DOI): http://dx.doi.org/doi:10.1108/IMR-04-2014-0144 


\section{Which cues cause consumers to perceive brands as more global? A conjoint analysis}

Purpose - The purpose of this paper is to investigate how the globalization (vs localization) of different cues (advertising copy, brand name, spokesperson, brand logo) influences consumers' perceived brand globalness.

Design/methodology/approach - The authors conducted conjoint analyses for two products differing in product category involvement (chocolates vs computer) with 200 consumers from the Netherlands. Additionally, based on cluster analysis, the authors divide respondents into two groups: local vs global consumer culture individuals, and the authors compare the results of the conjoint analysis for these two clusters.

Findings - Advertising copy is most important in determining perceived brand globalness. The spokesperson and the brand logo determine perceived brand globalness more strongly for a lowinvolvement product, whereas the brand name is more important for a high-involvement product. Further, the spokesperson and the brand logo are relatively more important for global consumer culture individuals, while local consumer culture individuals find the brand name and advertising copy relatively more important.

Practical implications - The most important cue to position a brand as global is the advertising copy. Brand managers of a low-involvement product and/or targeting global-minded consumers should concentrate on the spokesperson and the brand logo to position their brand. Managers of a high-involvement product and/or targeting local-minded people should focus on the brand name.

Originality/value - While a number of researchers have emphasized the importance of perceived brand globalness for international consumer behavior, the present study is the first to the authors' knowledge to investigate the relative importance of different cues in creating perceptions of brand globalness.

Keywords - Cluster analysis, Conjoint analysis, Global and local consumer culture positioning, Perceived brand globalness

To cite this document: Sarah De Meulenaer Nathalie Dens Patrick De Pelsmacker, (2015),"Which cues cause consumers to perceive brands as more global? A conjoint analysis", International Marketing Review, Vol.32 Iss 6 pp. 606 - 626 


\section{Introduction and purpose}

It is a prominent reality that markets are becoming more globalized (Özsomer and Altaras, 2008). The demand for global brands is strong, especially among particular consumer segments (Akaka and Alden, 2010). Studies show that consumers often see global brands as key symbols of quality, prestige, a global myth for being trendy and modern and even a stamp for social responsibility (Dogerlioglu-Demir and Tansuhaj, 2011; Gammoh et al., 2011; Holt et al., 2004; Steenkamp et al., 2003). As a result, the brand equity of global brands is often superior to that of local brands (Zou and Volz, 2010). Roy and Chau (2011) and Steenkamp et al. (2003) found that global brands are generally preferred over local brands. Brand managers could therefore strengthen their brand equity by explicitly positioning their brand as global (Gammoh et al., 2011). What is crucial for a successful global positioning is an understanding of how consumers' perceptions of globalness are formed (Akaka and Alden, 2010). If brands wish to position themselves as global, which elements should they manipulate to influence consumers' perceptions? Research on the antecedents of consumers' perceptions of brand globalness is extremely scarce. Although it has been suggested that perceived brand globalness can be achieved through the use of global symbols (i.e. brand name, symbols, themes, brand logo, spokesperson) in marketing communications (Alden et al., 1999), it is unclear which of these symbols most strongly influence consumers' perceptions (Swoboda et al., 2012).

We aim to fill this gap in the literature by investigating the relative importance of different advertising and branding cues in determining perceived brand globalness. Based on semiotics theory, Alden et al. (1999) proposed three types of cues in advertising that could associate a brand with global, local or foreign consumer culture: language, aesthetic styles and story themes. By means of a conjoint analysis, we test the relative importance of four cues (i.e. spokesperson, advertising copy, brand logo and brand name) drawn from Alden et al.'s (1999) positioning framework. The purpose of this paper is to test which of these cues more strongly impacts a brand's perceived globalness. To our knowledge, it is the first application of conjoint analysis in the context of international advertising. Previous conjoint analyses in the international marketing context have mainly focussed on the importance of a country-of-origin cue in comparison with other product attributes (Ahmed et al., 2004; Bruning, 1997; d'Astous and Ahmed, 1999) and on cross-cultural differences in consumers' preferences for different product attributes in automobiles and color televisions (Diamantopoulos et al., 1995; Ettenson, 1993).

The second purpose of the present study is to investigate to what extent the relative importance of the antecedents of brand globalness is influenced by the product category. To that end, we conduct the above-mentioned conjoint analysis for two products differing in product category involvement (computers and chocolate). Based on the elaboration likelihood model (ELM) (Petty and Briñol, 2008; Petty et al., 1981), we propose that the four cues under study will have a different importance for low- and high-involvement products.

The third objective is to explore the influence of consumers' cultural characteristics on the formation of perceived brand globalness. A number of authors have already established that differences in cultural values influence consumer perceptions of advertising (e.g. Kates and Goh, 
2003; Liang et al., 2011). Prior research indicates that consumer culture is an important moderator to consumer's responses to global (vs local) advertising (Gammoh et al., 2011; Nijssen and Douglas, 2011). We will therefore compare the relative importance of cues between two consumer groups; the global consumer culture vs the local consumer culture group. The global consumer culture group are individuals who are positively predisposed toward the effects of globalization, recognize the commonalities rather than dissimilarities among people around the world, and are interested in global events (Steenkamp and de Jong, 2010; Zhang and Khare, 2009). The local consumer culture group consists of individuals who have faith in and respect for local traditions and customs, are interested in local events, and recognize the uniqueness of local communities (Steenkamp and de Jong, 2010). Even though a number of studies have investigated to what extent local and global consumers prefer local vs global brands or local positioning vs global positioning advertisements (Akaka and Alden, 2010; Alden et al., 1999; Okazaki et al., 2010), to our knowledge, no research exists that has investigated the extent to which these consumers use certain advertising and branding cues differently in determining perceived brand globalness. However, previous research provides circumstantial evidence that local and global consumers might evaluate advertising and branding cues in a different way (Aaker and Maheswaran, 1997; De Mooij and Hofstede, 2010; Liang et al., 2011).

Both practitioners and academics are interested in understanding how consumers perceive global brands and how consumer perceptions of global brands are shaped (Özsomer et al., 2012). The results of this study should allow brand managers to more efficiently use advertising and branding cues to achieve a global brand positioning. In addition, it will contribute to the academic understanding of the determinants of perceived brand globalness, which in turn has been shown to affect consumers' attitude toward the brand and purchase intentions (Gammoh et al., 2011; Steenkamp et al., 2003). This is examined through a conjoint analysis, which can determine how people value different advertising and branding cues. Additionally, we examine whether the importance of different cues is influenced by product characteristics and/or by consumer characteristics.

\section{Theoretical background}

\subsection{Perceived brand globalness}

The term "global brand" has been defined in two ways (Özsomer and Altaras, 2008). The first school of thought defines a global brand as a brand with high-actual reach and availability (Dimofte et al., 2010). In this respect, only a relatively small number of brands are truly global (Nijssen and Douglas, 2011; Sinclair and Wilken, 2009). The second school of thought focusses on consumer perceptions (Alden et al., 2006; Özsomer, 2012; Steenkamp et al., 2003). In these studies, brand globalness is defined as the extent to which the brand is perceived as global (Steenkamp et al., 2003). The present paper follows the latter line of reasoning. We focus on perceived brand globalness as our key dependent variable.

Perceived brand globalness is an important variable in explaining international consumer behavior. Numerous studies point out that it has a positive effect on perceived brand quality 
(Dimofte et al., 2008, 2010; Holt et al., 2004; Özsomer, 2012; Steenkamp et al., 2003). Perceived brand globalness stimulates consumer perceptions of brand superiority, even when the quality and value are not objectively superior (Dimofte et al., 2008; Özsomer and Altaras, 2008). Further, global brands receive more esteem ( Johansson and Ronkainen, 2005), are perceived as symbols of cultural ideals (Holt et al., 2004), enjoy a higher social status (Dimofte et al., 2010) and generally have an advantage over local brands (Holt et al., 2004). In sum, previous research has shown that perceived brand globalness is a key variable that has a positive effect on several important outcome variables. However, what remains unclear is what determines perceived brand globalness. To identify possible antecedents of perceived brand globalness, we use Alden et al.'s (1999) consumer culture positioning theory which is discussed below.

\subsection{Consumer culture positioning}

Alden et al. (1999) identify three positioning strategies for brands in an international context. First, marketers can use a "global consumer culture positioning" by associating their brand with a widely understood and recognized set of global symbols, such as a global celebrity. On the other hand, marketers may opt to select a more "local consumer culture positioning" in which the brand is associated with the local consumer culture (e.g. Budweiser's association with small-town American culture in its US advertising) (Alden et al., 1999; Özsomer, 2012). A third positioning strategy is "foreign consumer culture positioning," where the brand is associated with a specific foreign culture (e.g. Gucci positions itself across the globe as an Italian brand). As only 3.8 percent of the advertisements use a foreign consumer culture positioning (Alden et al., 1999), we only focus on global and local consumer culture positioning in the present study, further referred to as global and local positioning.

Based on semiotics theory, Alden et al. (1999) identify a positioning framework that focusses on the use of verbal (language), visual (aesthetic styles) and thematic (story themes) cues to associate a brand with global or local consumer culture. The verbal dimension relates to the language of the advertising copy and brand name. One way for a brand to communicate global positioning is to use English words in its communications (Alden et al., 1999). As English is the primary language of international business, the mass media and the internet, it signals internationalism to many consumers (Alden et al., 1999). In contrast, brand managers wanting to emphasize local positioning might use the local language. Additionally, the content of advertising, such as the brand slogan, can support the local relevance through adaptation (e.g. "Merrill Lynch is Bullish on America") or signal globalness (e.g. Citibank: "the whole world in one bank") (Kates and Goh, 2003).

The aesthetic or visual dimension relates to the use of (famous) spokespersons and brand logos. While certain characteristics of a spokesperson can be associated with local culture prototypes (e.g. a Bollywood actor in an Indian advertisement), other characteristics can reflect a global positioning and give the brand a more global image (e.g. Michael Jordan for Nike). A second visual aspect is the brand logo. The appearance of some logos is tied less to specific cultures (e.g. Nike's swoosh, AT\&T's abstract globe), while others may be more symbolic of a specific cultural tradition (e.g. Le Petit Marseillaise's little boy with a striped Breton shirt and beret, 
Qantas' kangaroo) (Alden et al., 1999).

In the present study, two verbal cues, namely, the advertising copy and the brand name, and two visual cues, the spokesperson and the brand logo, are tested as possible antecedents of perceived brand globalness. Alden et al. (1999) have asserted that each of these four cues is used to communicate both local positioning and global positioning in advertising worldwide. Alden et al. (1999) also propose a third dimension, which refers to story-related themes. However, one of the important characteristics of a cue in a conjoint analysis is that it should be easily communicated and put into practice (Hair et al., 2006). As the current study uses print ads, the theme would be difficult to convey and would also confound with the advertising copy and visuals. Therefore, we did not include any cues relating to adverting themes in this study.

Previous research has looked into which cues are important for a successful global approach. For example, Yin (1999) found that foreign companies advertising in China estimated that the three most important cues to manipulate were the language of the ads, the product attributes and the models or spokespersons. Zhou and Belk (2004) used a reader-response approach and found that a global appeal is largely triggered by the product category, an ad's symbolic meaning and the model used. Based on a content analysis, Nelson and Paek (2007) found that the brand name and the spokesperson are most likely to be standardized in advertising, while the advertising copy is not often standardized. These results confirmed the findings from an earlier content analysis by Harris and Attour (2003). However, none of these studies have investigated the extent to which these different cues trigger perceived brand globalness. Figure 1 shows our conceptual framework. Four cues are considered as antecedents of perceived brand globalness. First, we try to answer the following research question:

RQ1. What is the relative importance of the advertising copy, the brand name, the spokesperson and the brand logo in an advertisement in evoking perceived brand globalness?

Additionally, we examine whether the relative importance of these antecedents is moderated by product category involvement and consumer culture.

\subsection{The role of product category involvement}

Based on the ELM (Petty and Briñol, 2008; Petty et al., 1981), the relative importance of the four cues under study should differ between low- and high-involvement products. The ELM predicts that high-product category involvement leads consumers to use a systematic information processing strategy (central route) in which message-based cognitions are important. Attitude change is driven by the careful consideration of, and idiosyncratic responses to central cues, which are relevant arguments supporting the advocated position (Areni, 2003). In the present study, the advertising copy and the brand name are considered as central cues. Previous research has indicated that verbal claims and product attributes are relatively more important for people who are highly involved or motivated (Garretson and Burton, 2005). This indicates that the advertising copy in our study can be considered as a central cue, which will more strongly influence the perceived brand globalness for high-involvement products. Second, we also 
consider the brand name to be a central cue. A brand name represents a cognitive structure, a network of associations built on organized knowledge about the brand (Braun-LaTour and LaTour, 2004). For a new brand name, as is the case in this study, by definition, no previous network of associations exists (Campbell and Keller, 2003). As a result, categorization based on the brand name will be inhibited because of the absence of a brand category in consumers' minds. Categorization theory (Fiske and Pavelchak, 1986) then predicts that consumers will revert to more piece-meal processing as a basis for forming an evaluation. As a result, new brands should engender more central processing (Dens and De Pelsmacker, 2010; Campbell and Keller, 2003), and thus the brand name could be considered a central cue.

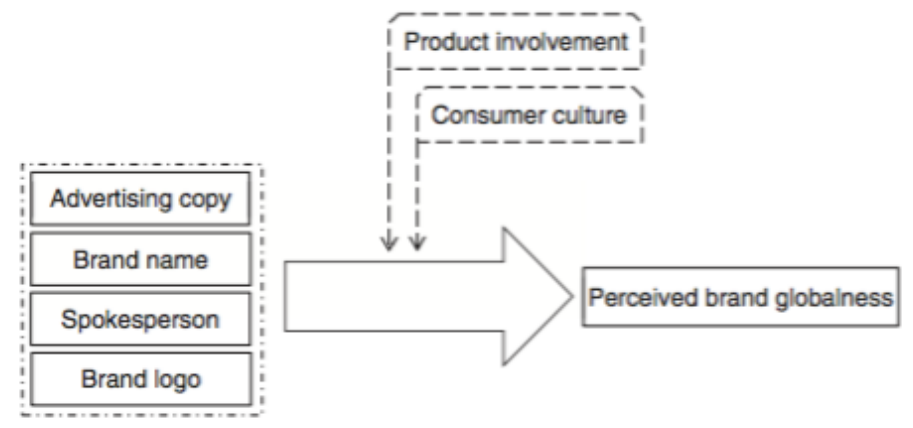

Figure 1. Conceptual framework

Low-product category involvement leads consumers to using a heuristic processing strategy (peripheral route), based on simple decision rules (e.g. how-do-I-feel-about-it?) (Chaiken, 1980). Low-involvement individuals do generally not elaborately consider the message content. Instead, they use non-content elements, often called peripheral cues, associated with the message as a basis for attitude formation (Lien, 2001). Factors such as expertise, credibility, likeability or attractiveness of the spokesperson have been found to serve as peripheral cues (Lien, 2001; Petty and Cacioppo, 1986). Further, research has shown that the impact of pictures without productrelevant information is greater under low involvement (Lien, 2001; Miniard et al., 1991). Since the brand logo used in our advertisements does not contain product information, this cue is also considered as peripheral.

A general assumption of the ELM is that a tradeoff exists between central and peripheral processing (Lien, 2001). As argument scrutiny increases, central cues become more important determinants of persuasion, and peripheral cues become less important determinants. We therefore hypothesize the following:

H1. To evoke perceived brand globalness: (a) advertising copy has a greater relative importance for high-involvement products than for low-involvement products; (b) the brand name has a greater relative importance for high-involvement products than for low-involvement products; (c) the spokesperson has a greater relative importance for low-involvement products than for high involvement products; (d) the brand logo has a greater relative importance for low-involvement 
products than for high-involvement products.

\subsection{The role of consumer culture}

We also investigate to what extent the relative importance of cues differs between global consumer culture and local consumer culture segments. Culture-specific variations in cue diagnosticity may influence how consumers from different cultures derive brand globalness, based on advertising and branding cues (Aaker and Maheswaran, 1997; De Mooij and Hofstede, 2010; Liang et al., 2011).

The "global consumer culture" segment (hereafter referred to as global segment) includes individuals who are positively predisposed toward the effects of globalization, recognize the commonalities rather than dissimilarities among people around the world, and are interested in global events (Steenkamp and de Jong, 2010; Zhang and Khare, 2009). Global consumers attempt to find meaning in their lives as consumers through the consumption of products that are generally recognized as international and transcending individual national cultures (Steenkamp and de Jong, 2010). These consumers use global brands to create an imagined identity that they share with like-minded people (Hannerz, 1990; Holt et al., 2004). Their ownership and use of global brands function as a passport to global citizenship (Strizhakova et al., 2008). They are attracted to the "shared consciousness" and the cultural meanings produced by globalization (Holton, 2000; Steenkamp and de Jong, 2010). The "local consumer culture" segment (local segment) consists of individuals who have faith in and respect for local traditions and customs, are interested in local events, and recognize the uniqueness of local communities (Steenkamp and de Jong, 2010). Local consumers value products that are indigenously conceived and controlled and products that are comparatively rich in distinctive local content (Steenkamp and de Jong, 2010).

To measure consumers' affinity with global vs local consumer culture, different constructs have been used (Gammoh et al., 2011; Nijssen and Douglas, 2011). We define consumers as belonging to a local or a global segment based on four cultural constructs: acculturation to global consumer culture, consumer ethnocentrism, belief in global citizenship and consumer worldmindedness. Acculturation to global consumer culture encompasses personal dispositions toward globalization and foreign cultures (cosmopolitanism, openness toward the lifestyles and consumption symbols of other countries, as well as an outright identity with global consumer culture), the influences of media and marketing (specifically, global/foreign mass media exposure and exposure to multinational marketing activities), foreign traveling attitudes/ experiences, as well as English-language fluency and use (Cleveland et al., 2013). Consumer ethnocentrism represents the belief held by consumers about the appropriateness of purchasing foreign-made products (Shimp and Sharma, 1987). For some, foreign brands constitute economic and cultural threats (Cleveland et al., 2013). Biases toward locally-produced products signify resistance toward globalization (Steenkamp et al., 2003). Third, belief in global citizenship measures the belief in brands as a passport to global citizenship, defined as a person's perception that global brands create an imagined global identity (Strizhakova et al., 2008). The last construct, consumer world-mindedness, indicates the willingness to adapt to and try products from other countries and 
cultures and the openness to other cultures and lifestyles (Nijssen and Douglas, 2011). By combining different constructs, we identify consumers' inclination toward global or local consumer culture in a complete and nuanced way.

Previous research provides circumstantial evidence that local and global consumers might evaluate advertising and branding cues in a different way. Content analyses of existing ads reveal that the advertising copy (i.e. headline, body copy and slogan) is the element that is most often adapted to local culture (Harris and Attour, 2003; Nelson and Paek, 2007). Kates and Goh (2003) also indicate that the manipulation of the slogan is crucial to gain local relevance. Native language ads are more likely to elicit self-referent thoughts about family, friends, home or the homeland and to evoke a sense of belonging and closeness (Krishna and Ahluwalia, 2008; Noriega and Blair, 2008). This could indicate that practitioners expect consumers to place a relatively great importance on advertising copy to signal globalness or localness. Because the advertising copy is usually adapted, their working hypothesis seems to be that especially local consumers will rely on advertising copy to determine their perceived brand globalness. Second, the brand name is an element that is frequently manipulated to study consumers' responses toward global and local brands (e.g. Akram et al., 2011; Sichtmann and Diamantopoulos, 2013; Steenkamp et al., 2003). For lowly ethnocentric consumers (a characteristic of global consumers), a global brand name leads to more positive perceptions of prestige and quality (Akram et al., 2011; Steenkamp et al., 2003). Similarly, Rajabi (2014) found that a global brand name stimulates self-brand congruity for global consumers. Noriega and Blair (2008) indicate that adapting the brand name to the local language increases self-referent thoughts about family, friends, home or homeland, but make no distinction between local or global consumers.

With respect to visual cues, research indicates that the presence of ethnic cues in advertisements (e.g. a local model or celebrity) can match with the ethnic identity of individuals, which is one of fundamental dimensions of the self-concept (Carrus et al., 2009). Others have found that global celebrities are associated with status, modernity, cosmopolitan sophistication and technology (Zhou and Belk, 2004) and can increase the prestige of the brand (Steenkamp, 2013). To our knowledge, explicit comparisons between local and global consumers are lacking in this area. Finally, global brands have a perceived social cachet and can be particularly attractive as selfexpressive markers and identity forgers (Dimofte et al., 2010). Therefore, a global brand logo may be particularly relevant for global consumers who want to signal their membership of the worldwide consumer segment.

Since previous research provides little guidance to formulate directional hypotheses on the relative importance of each of the cues under study for local and global consumers, we pose the following research question:

RQ2. Is there a difference between local and global segments in the relative importance of the advertising copy, the brand name, the spokesperson, and the brand logo in evoking perceived brand globalness, and does this depend on product category involvement? 


\section{Method}

\subsection{Conjoint analysis: attributes and levels}

We conduct two separate conjoint analyses for two products: chocolates (low involvement) and computers (high involvement) (based on Dens and De Pelsmacker, 2010). The objective of conjoint analysis is to determine how much each of a number of attributes (advertising and branding cues) contributes to overall perception or preference. This makes conjoint analysis a suitable technique to answer our research questions. The technique consists of showing participants a controlled set of advertisements, varying in cues. By analyzing how respondents score each of these advertisements, the implicit valuation (utilities or part-worths) of the individual cues making up the advertisements can be determined.

Following the semiotics framework, we manipulate four attributes (see Table I for an overview). The first attribute is the advertising copy, which consists of the slogan, the website suffix and an availability statement. Because these three elements were combined into a single attribute, multiple levels of the attribute are advised in order to avoid inter-attribute correlation (Hair et al., 2006). Therefore, we defined three levels of this attribute: local, mixed and global positioning. The local positioning contains a Dutch slogan ("The best chocolate thanks to the best local ingredients" and "The power of a network. Across the Netherlands."), a local website suffix ".nl," and states that the product is "available in the Netherlands." The global positioning consists of a global slogan ("The best chocolate thanks to the best ingredients around the world." and "The power of a network. Across the world"), a global website suffix ".com" and states "available across the world." The mixed level combines a local slogan with a global website suffix and global availability. The second attribute is the brand name, for which we define two levels: local positioning (a Dutch brand name with an explicit reference to the Netherlands, the country under study, "Chocolade van Oranje" and "NL Computer") and global positioning (an English brand name, "Candy Colors" and "Worldwide Computers"). The third attribute, the spokesperson, was manipulated at two levels: local positioning (national celebrity, Lieke van Lexmond) and global positioning (international celebrity, Penelope Cruz). Both spokespersons are well-known actresses. In addition, a pretest showed that these two women do not differ significantly in terms of attractiveness, trustworthiness, likeability, expertise and fit with the product (Table II). This way, we wanted to control for spokesperson characteristics that may confound the results (Amos et al., 2008; Till and Busler, 2000). Finally, the fourth attribute is the brand logo, for which we defined two levels: local positioning (a crown to symbolize the Dutch monarchy) and global positioning (a globe). The different levels of the attributes were pretested (n 1/4 50) on perceived globalness (semantic differential, 0-10) to ensure that they would accurately signal local positioning and global positioning. As can be seen in Tables I and II, that was indeed the case (all $\mathrm{p} \leqslant 0.001)$. 


\begin{tabular}{|c|c|c|c|c|c|c|}
\hline Attributes & Product & Local positioning & $\begin{array}{l}\text { Perceived } \\
\text { globalness }\end{array}$ & Global positioning & $\begin{array}{l}\text { Perceived } \\
\text { globalness }\end{array}$ & $p$-Value \\
\hline \multirow[t]{2}{*}{$\begin{array}{l}\text { Advertising } \\
\text { copy: slogan }\end{array}$} & Computer & $\begin{array}{l}\text { The power of a } \\
\text { network. Across } \\
\text { the Netherlands }\end{array}$ & 3.52 & $\begin{array}{l}\text { The power of a } \\
\text { network. Across the } \\
\text { world }\end{array}$ & 7.05 & $<0.001$ \\
\hline & Chocolates & $\begin{array}{l}\text { The best } \\
\text { chocolate thanks } \\
\text { to the best local } \\
\text { ingredients }\end{array}$ & 3.05 & $\begin{array}{l}\text { The best chocolate } \\
\text { thanks to the best } \\
\text { ingredients around } \\
\text { the world }\end{array}$ & 7.71 & $<0.001$ \\
\hline \multirow[t]{2}{*}{ Brand name } & Computer & NL computer & 3.90 & $\begin{array}{l}\text { Worldwide } \\
\text { Computers }\end{array}$ & 8.74 & $<0.001$ \\
\hline & Chocolates & $\begin{array}{l}\text { Chocolade van } \\
\text { Oranje }\end{array}$ & 4.47 & Candy Colors & 7.07 & $<0.001$ \\
\hline Spokesperson & $\begin{array}{l}\text { Both } \\
\text { products }\end{array}$ & $\begin{array}{l}\text { Lieke van } \\
\text { Lexmond }\end{array}$ & 2.09 & Penelope Cruz & 6.27 & 0.001 \\
\hline Brand logo & $\begin{array}{l}\text { Both } \\
\text { products }\end{array}$ & & 4.57 & & 9.40 & $<0.001$ \\
\hline
\end{tabular}

Note: $p$-Values result from within-subjects (brand name, brand logo, slogan) or between-subjects (spokesperson) $t$-test between the global and local positioning levels for each attribute

Table I. Manipulated attributes and levels

\begin{tabular}{lccc}
\hline Characteristic & Penelope Cruz & Lieke van Lexmond & $p$-Value \\
\hline Attractiveness & 5.79 & 5.46 & 0.366 \\
Trustworthiness & 4.70 & 5.05 & 0.238 \\
Likeability & 5.06 & 5.36 & 0.290 \\
Product expertise (computer) & 3.00 & 3.33 & 0.335 \\
Product expertise (chocolates) & 3.80 & 3.55 & 0.462 \\
Perceived fit with product (computer) & 2.76 & 3.33 & 0.708 \\
Perceived fit with product (chocolates) & 4.11 & 3.97 & 0.120
\end{tabular}

Table II. Celebrity characteristics (pretest)

\subsection{Data collection and sample}

The data were collected through a professional market research agency via an online web survey in the Netherlands. The study was conducted in the Netherlands because prior research indicates that the Dutch do not show a particular preference for either local or global products (Steenkamp and de Jong, 2010). As such, by choosing the Netherlands, we avoid that the results from the study would by distorted by an initial respondent bias toward global or local positioning elements. It should be noted that a conjoint analysis is an intensive task for respondents. Respondent fatigue with the conjoint task or disinterest in the research task can affect the effort devoted to completing the conjoint measurement. We worked with a professional market research agency to ensure the quality of the collected data. First, the panel members have a vast experience with online surveys and are typically motivated to participate. Additionally, we only included fully completed questionnaires in our analyses and performed a quality check by rejecting respondents who rated all eight advertisements in the same way, or provided the same answer to reverse-scaled items. The final sample consists of 100 unique respondents for each product category (chocolates and computers) (44 percent men, average age: 47 years). 


\subsection{Measures}

We used SPSS orthoplan to produce a balanced orthogonal design of eight advertisements that is constructed by selecting one level of each attribute per advertisement. A balanced design means that each level within an attribute appears an equal number of times across the eight stimuli. In an orthogonal design, the levels of the attributes are chosen such that, for each pair of attributes (say, $a$ and $b$ ), the high-level a appears equally often in profiles that have a high-level $b$ as in profiles that have a low-level $b$, and vice versa. This design is extremely efficient for estimating partworths, and is therefore often used (Ahmed et al., 2004; Bruning, 1997; Diamantopoulos et al., 1995; Ettenson, 1993). One of the limitations of an orthogonal design is that it confounds interactions, so that it only allows estimating main effects. However, adding interaction would substantially increase the number of stimuli to be presented to participants, whereas the increased power is in most cases minimal (Green and Srinivasan, 1990). We also employed traditional fullprofile conjoint analysis, where respondents score all eight advertisements, because of its perceived realism (Hair et al., 2006).

Participants were exposed to all eight advertisements in a randomized order and had to indicate perceived brand globalness on a three-item, 11-point semantic differential (Steenkamp et al., 2003) ( $\alpha 1 / 40.904)$. As a conjoint analysis involves a relatively large number of stimuli to be evaluated, it is useful to expand the number of response categories over that found in most consumer surveys. A basic rule of thumb is to use 11 categories for 16 or fewer stimuli (Hair et al., 2006). Participants were instructed to score the eight advertisements independently from each other, thus not taken into account the previous version they had seen. After the respondents rated each of the eight advertisements, we measured their product category involvement on a threeitem seven-point semantic differential scale (Dens and De Pelsmacker, 2010) ( $\alpha$ 1/4 0.911). The cultural constructs were measured on multi-item five-point Likert scales: acculturation to global consumer culture (25 items, Cleveland et al., 2013) ( $\alpha 1 / 40.872$ ), consumer ethnocentrism (four items, Steenkamp et al., 2003) ( $\alpha$ 1/4 0.830), consumer world-mindedness (eight items, Nijssen and Douglas, 2011) ( $\alpha$ 1/4 0.753) and belief in global citizenship (three items, Strizhakova et al., 2008) ( $\alpha$ 1/4 0.929). Finally, we measured respondents' age, gender and education. For multiitem measures, the average of the different items was taken to compute the construct score.

\section{Results}

SPSS-conjoint was used to carry out the analyses. For each respondent, the analysis computes the relative importance of each attribute based on the part-worth utility for each level of each attribute. The total part-worth utilities and relative importance of the attributes are calculated for the total sample by averaging the individual scores. The correlation between the actual and predicted preferences is calculated for each person and tested for statistical significance. In the total sample, the total correlation is 0.998 and significant, indicating a good fit (Hair et al., 2006).

Table III shows the part-worths for each attribute level across the two products. More positive part-worths indicate a higher perceived brand globalness. As expected, the global positioning levels of all the attributes correspond with higher perceived brand globalness, confirming that our 
manipulations were successful. In the last column, the relative importance percentages per attribute are shown. The range of the part-worths (highest to lowest) for each attribute provides a measure of how important the attribute is to signal brand globalness. Attributes with greater partworth ranges play a more important role than those with smaller ranges. The importance percentages are computed by taking the utility range for each attribute separately and dividing it by the sum of the utility ranges for all attributes. Consequently, the percentages sum up to 100 . Advertising copy is the most important cue in signaling brand globalness (40.1 percent). When we consider the three levels, we see that the part-worth utility increases by 0.52 for each level. This indicates that the manipulation of the slogan is equally important as the manipulation of the website suffix and the availability statement. The importance rating of the spokesperson is 28.8 percent, of the brand name 24.0 percent. With 7.2 percent, the brand logo is the least important cue.

Next, we examine whether these relative importance values differ between a low- and highinvolvement product (H1). As expected, computers (M1/45.45) score significantly higher on product category involvement than chocolates (M1/44.39) (t(198) 1/4 6.255, p o 0.001). In order to test $\mathrm{H} 1$, we conduct a separate conjoint analysis for the two products. Table IV shows the average part-worth utilities for each level, and the relative importance of the four cues, per product category. The conjoint analyses show that advertising copy is the most important cue to signal globalness for both product types. For the low-involvement product, this is followed by the spokesperson, than the brand logo and lastly the brand name. For the high-involvement product, in terms of relative importance, the advertising copy is followed by the brand name, the spokesperson and the brand logo, respectively. The advertising copy is approximately equally important for a low-involvement product, chocolates (41.3 percent) and for a high-involvement product, computers $(39.0$ percent), rejecting H1a. The brand name is relatively much more important for computers (35.6 percent) than for chocolates (11.5 percent), confirming H1b. As expected in $\mathrm{H} 1 \mathrm{c}$, the spokesperson is relatively more important for chocolates (34.9 percent) than for a computer (23.1 percent). H1d is also supported, as the brand logo is relatively more important for chocolates (12.3 percent) than for computers ( 2.4 percent).

\begin{tabular}{llcc}
\hline Attribute & Level & Part-worth utility & Relative importance (\%) \\
\hline Advertising copy & Local positioning & -0.52 & 40.1 \\
& Mixed positioning & 0.00 & \\
\multirow{2}{*}{ Brand name } & Global positioning & 0.52 & 24.0 \\
Spokesperson & Local positioning & -0.31 & 28.8 \\
Brand logo & Global positioning & 0.31 & 7.2 \\
\multirow{2}{*}{ Notes: $n=200$. Pearson's $R=0.998$ ( $p<0.001)$} & -0.37 & \\
\hline
\end{tabular}

Table III. Conjoint analysis results across product categories 
In order to answer RQ2, respondents were assigned to one of two groups based on a cluster analysis using their individual scores on the four cultural constructs: acculturation to global consumer culture, consumer ethnocentrism, belief in global citizenship and consumer worldmindedness. From a theoretical viewpoint, we expect to find two groups: a global consumer culture oriented and a local consumer culture- oriented group. Based on the results of a hierarchical cluster analysis using Ward's method, we see that two clusters are indeed the best solution. As suggested by Hair et al. (2006), once the optimal number of clusters was determined, we performed a K-means cluster analysis to assign individuals to clusters. The first cluster, which represents the local segment (n1/4106), scores high on consumer ethnocentrism, and low on acculturation to global consumer culture, belief in global citizenship and world-mindedness (see Table V). The second cluster, the global segment (n 1/4 94), scores low on consumer ethnocentrism and high on the other constructs. As the first conjoint analyses (H1) revealed substantial differences in cue importance between the low and the high-involvement product, we conducted conjoint analyses for each consumer segment per product category, resulting in four different conjoint analyses (Tables VI and VII).

\begin{tabular}{|c|c|c|c|c|c|c|}
\hline \multirow[b]{2}{*}{ Attribute } & \multirow[b]{2}{*}{ Level } & \multicolumn{2}{|c|}{$\begin{array}{l}\text { Low involvement } \\
\qquad(n=100)\end{array}$} & \multicolumn{2}{|c|}{$\begin{array}{l}\text { High involvement } \\
\qquad(n=100)\end{array}$} & \multirow{2}{*}{$\begin{array}{c}\text { Difference } \\
\text { in } \\
\text { importance } \\
(\%)\end{array}$} \\
\hline & & $\begin{array}{l}\text { Part- } \\
\text { worth } \\
\text { utility }\end{array}$ & $\begin{array}{c}\text { Relative } \\
\text { importance } \\
(\%)\end{array}$ & $\begin{array}{l}\text { Part- } \\
\text { worth } \\
\text { utility }\end{array}$ & $\begin{array}{c}\text { Relative } \\
\text { importance } \\
(\%)\end{array}$ & \\
\hline \multirow[t]{3}{*}{ Advertising copy } & Local positioning & -0.50 & 41.3 & -0.55 & 39.0 & -2.3 \\
\hline & Mixed positioning & -0.05 & & 0.06 & & \\
\hline & Global positioning & 0.55 & & 0.49 & & \\
\hline Brand name & Local positioning & $\begin{array}{r}-0.15 \\
0.15\end{array}$ & 11.5 & $\begin{array}{r}-0.47 \\
0.47\end{array}$ & 35.6 & -24.1 \\
\hline \multirow[t]{2}{*}{ Spokesperson } & Local positioning & -0.44 & 34.9 & -0.31 & 23.1 & 11.8 \\
\hline & Global positioning & $\begin{array}{r}0.44 \\
-0.16\end{array}$ & & $\begin{array}{r}0.31 \\
-0.03\end{array}$ & & \\
\hline Brand logo & $\begin{array}{l}\text { Local positioning } \\
\text { Global positioning }\end{array}$ & $\begin{array}{r}-0.16 \\
0.16\end{array}$ & 12.3 & $\begin{array}{r}-0.03 \\
0.03\end{array}$ & 2.4 & 9.9 \\
\hline otes: Pearson's & $R_{\text {Low involvement }}=0$. & $(p<1$ & 1); Pearson & High in & ment $=0.990$ & $<0.001)$ \\
\hline
\end{tabular}

Table IV . Conjoint analysis results - low vs high-involvement product category 


\begin{tabular}{lccc}
\hline & $\begin{array}{c}\text { Local } \\
\text { segment (M) }\end{array}$ & $\begin{array}{c}\text { Global } \\
\text { segment (M) }\end{array}$ & $\begin{array}{c}\text { ANOVA } \\
\text { sig. }\end{array}$ \\
\hline $\begin{array}{l}\text { Acculturation openness to global consumer culture } \\
\text { Acculturation cosmopolitanism }\end{array}$ & 2.94 & 3.80 & $<0.001$ \\
Acculturation exposure to marketing activities of & 3.04 & 3.93 & $<0.001$ \\
multinational corporations & & & \\
Acculturation English-language use & 2.85 & 3.23 & $<0.001$ \\
Acculturation traveling frequencies & 2.79 & 3.49 & $<0.001$ \\
Acculturation global mass media exposure & 2.95 & 3.95 & $<0.001$ \\
Acculturation self-identification with global consumer & 3.34 & 4.01 & $<0.001$ \\
culture & & & \\
Ethnocentrism & 2.20 & 2.68 & $<0.001$ \\
Global belief & 2.65 & 2.29 & 0.001 \\
World mindedness & 2.60 & 3.23 & $<0.001$ \\
& 3.26 & 3.70 & $<0.001$ \\
\hline
\end{tabular}

Table V. Consumer culture clusters and centers

For the low-involvement product, chocolate, the advertising copy is the most important cue and the spokesperson the second most important cue for both segments. For the local segment, the brand name follows as third and finally the brand logo, while this is the opposite for the global segment. The advertising copy and the brand name are relatively more important for the local segment (respectively, 44.5 and 12.6 percent) than for the global segment (respectively, 38.5 and 1.5 percent). On the other hand, the brand logo is more important for global segment (16.4 percent) in comparison with local segment (7.7 percent). There is virtually no difference between the two segments with respect to the importance of the spokesperson. The conjoint analyses for the high involvement product, computers, again show that advertising copy is the most important cue and the brand logo the least important cue for both segments. The local segment finds the brand name the second most important, followed by the spokesperson and the brand logo. The global segment finds the spokesperson most important after advertising copy, followed by the brand name and the brand logo. Advertising copy and the brand name are relatively more important for the local segment (respectively, 44.0 and 41.9 percent) in comparison with the global segment (resp. 34.3 and 29.7 percent). In contrast, the spokesperson and the brand logo determine perceived brand globalness more for the global segment (respectively, 31.3 and 4.7 percent) relative to the local segment (respectively, 14.0 and 0.1 percent), although the difference in brand logo importance is quite small. 


\begin{tabular}{|c|c|c|c|c|c|c|}
\hline Attributes & Level & $\begin{array}{l}\text { Loca } \\
\text { Part- } \\
\text { worth } \\
\text { utility }\end{array}$ & $\begin{array}{l}1 \text { segment } \\
\text { Relative } \\
\text { importance } \\
(\%)\end{array}$ & $\begin{array}{l}\text { Globe } \\
\text { Part- } \\
\text { worth } \\
\text { utility }\end{array}$ & $\begin{array}{l}\text { A segment } \\
\text { Relative } \\
\text { importance } \\
(\%)\end{array}$ & $\begin{array}{c}\text { Difference } \\
\text { in } \\
\text { importance } \\
(\%) \\
\end{array}$ \\
\hline Advertising copy & $\begin{array}{l}\text { Local positioning } \\
\text { Mixed positioning } \\
\text { Global positioning }\end{array}$ & $\begin{array}{r}-0.45 \\
-0.08 \\
0.53\end{array}$ & 44.5 & $\begin{array}{r}-0.56 \\
-0.02 \\
0.59\end{array}$ & 38.5 & 6.0 \\
\hline Brand name & $\begin{array}{l}\text { Local positioning } \\
\text { Global positioning }\end{array}$ & $\begin{array}{r}-0.14 \\
0.14\end{array}$ & 12.6 & $\begin{array}{r}-0.16 \\
0.16\end{array}$ & 1.5 & 11.1 \\
\hline Spokesperson & $\begin{array}{l}\text { Local positioning } \\
\text { Global positioning }\end{array}$ & $\begin{array}{r}-0.39 \\
0.39\end{array}$ & 35.2 & $\begin{array}{r}-0.51 \\
0.51\end{array}$ & 34.6 & 0.6 \\
\hline Brand logo & $\begin{array}{l}\text { Local positioning } \\
\text { Global positioning }\end{array}$ & $\begin{array}{r}-0.08 \\
0.08\end{array}$ & 7.7 & $\begin{array}{r}-0.24 \\
0.24\end{array}$ & 16.4 & -8.7 \\
\hline
\end{tabular}

Table VI. Conjoint analysis results - local vs global segment (low-involvement product category)

\begin{tabular}{|c|c|c|c|c|c|c|}
\hline Attributes & Level & $\begin{array}{l}\text { Loca } \\
\text { Part- } \\
\text { worth } \\
\text { utility }\end{array}$ & $\begin{array}{c}1 \text { segment } \\
\text { Relative } \\
\text { importance } \\
(\%)\end{array}$ & $\begin{array}{c}\text { Global } \\
\text { Part- } \\
\text { worth } \\
\text { utility } \\
\end{array}$ & $\begin{array}{c}\text { segment } \\
\text { Relative } \\
\text { importance } \\
(\%)\end{array}$ & $\begin{array}{c}\text { Difference } \\
\text { in } \\
\text { importance } \\
(\%)\end{array}$ \\
\hline Advertising copy & $\begin{array}{l}\text { Local positioning } \\
\text { Mixed positioning } \\
\text { Global positioning }\end{array}$ & $\begin{array}{r}-0.59 \\
0.11 \\
0.48\end{array}$ & 44.0 & $\begin{array}{r}-0.50 \\
0.01 \\
0.50\end{array}$ & 34.3 & 9.7 \\
\hline Brand name & $\begin{array}{l}\text { Local positioning } \\
\text { Global positioning }\end{array}$ & $\begin{array}{r}-0.51 \\
0.51\end{array}$ & 41.9 & $\begin{array}{r}-0.43 \\
0.43\end{array}$ & 29.7 & 12.2 \\
\hline Spokesperson & $\begin{array}{l}\text { Local positioning } \\
\text { Global positioning }\end{array}$ & $\begin{array}{r}-0.17 \\
0.17\end{array}$ & 14.0 & $\begin{array}{r}-0.46 \\
0.46\end{array}$ & 31.3 & -17.3 \\
\hline Brand logo & $\begin{array}{l}\text { Local positioning } \\
\text { Global positioning }\end{array}$ & $\begin{array}{l}0.00 \\
0.00\end{array}$ & 0.1 & $\begin{array}{r}-0.07 \\
0.07\end{array}$ & 4.7 & -4.6 \\
\hline
\end{tabular}

Table VII. Conjoint analysis results - local vs global segment (high-involvement product)

In answer to RQ2, we see that both the global and the local segment find advertising copy the most important cue. However, this cue is even more important for local consumers than for global consumers. The differences between the two segments are more pronounced for the highinvolvement product category than for the low-involvement one. Especially for a highinvolvement product, the local segment finds advertising copy more important, while the global segment finds the spokesperson and brand logo relatively more important.

\section{Discussion and conclusion}

The present study represents the first investigation into the antecedents of perceived brand globalness that we are aware of. Since previous literature points out that perceived brand globalness can be associated with enhanced brand esteem, credibility, prestige, quality and purchase likelihood (Dimofte et al., 2008; Holt et al., 2004; Özsomer and Altaras, 2008; Steenkamp et al., 2003), it is interesting for both academics and managers to understand how this perception can be achieved through advertising and branding, and which elements contribute 
most to this perception. The results show that, by far, advertising copy most strongly contributes to perceived brand globalness, across product categories and consumer culture segments, with a relative importance of about 40 percent in most cases. The brand logo is often the least important cue, especially for a high-involvement product, where it only determines 2.4 percent of perceived brand globalness.

In line with the ELM (Cacioppo and Petty, 1984), peripheral cues (i.e. spokesperson and brand logo), are relatively more important for low involvement than for high-involvement products, while the brand name, which could be considered as a more central cue, more strongly determines perceived brand globalness for high-involvement products. In addition, our results also indicate that the perception of brand globalness is driven more by peripheral cues (i.e. the visual cues) for global-minded consumers and more by central cues (i.e. the verbal cues) for local-minded consumers. This is especially true for the high-involvement product, while the differences are less pronounced for the low-involvement product. This is interesting since some previous research has indicated that cultural characteristics are more important under low involvement, because cultural differences diminish as people engage in more effortful ad processing (Briley and Aaker, 2006; Liang et al., 2011). The results of the present research suggest otherwise. It could be that, under low involvement, consumers simply do not care enough about the different advertising elements to effectively judge the difference between all these cues and levels.

Peripheral cues can affect attitudes because they trigger relatively primitive affective states that become associated with the attitude object (Petty and Cacioppo, 1986). In the present study, this is mainly the case for global consumers. Possibly, global consumers are more led by visual cues that symbolize global status and prestige and membership of a particular global group (especially the endorser). Local advertising elements have often been related to self-congruity and selfrelevant thinking, which could be a more cognitive and central process. That could explain why local consumers are more prone to consider advertising copy. Ethnocentric consumers (a characteristic of local consumer culture), for example, have been found to be less influenced by the halo effect of global brands (Steenkamp et al., 2003), so it makes sense that they are less influenced by peripheral cues that support this halo effect, and search for other variables that serve as more persuasive arguments. However, as indicated earlier, previous research offers little direction or theoretical foundation as to why these two segments would differ in their formation of perceived brand globalness and this is definitely an interesting area for further research. Our results are consistent with the results of Kumar et al. (2009), who found that the affective component (e.g. emotional value) more strongly determines the purchase intention of global brands than the cognitive components (e.g. perceived quality). Our result also indicate that the common practice in advertising to standardize or globalize visual elements and locally adapt the subhead and slogan (Harris and Attour, 2003; Nelson and Paek, 2007) and to emphasize softselling techniques (indirect, image-oriented content) in global positioning and more hard-selling techniques (direct, strong message argument appeals) in local positioning (Alden et al., 1999), make sense. Indeed, the global segment is most susceptible to visual cues, so globalizing these cues should most positively impact the perceptions of brand globalness, and subsequently, brand 
attitude, for this segment. Contrarily, local consumers tend to favor local cues. As they seem most susceptible to verbal cues in deferring perceived brand globalness, it would make most sense to localize these cues and to use strong arguments as central cues.

\section{Implications}

This study provides an analysis based on the semiotic theory provided by Alden et al. (1999) on local positioning vs global positioning from a new perspective. The results indicate that advertising copy is the most essential part to signal globalness. The relative importance of the brand name, the spokesperson and the brand logo depends on the product category and on consumer culture. It appears that central cues (i.e. advertising copy and brand name) are more important under high involvement and for global-minded consumers, while peripheral cues (i.e. spokesperson and brand logo) are more essential under low involvement and for local-minded individuals. These results could be used by future (experimental) researchers as guidelines for manipulating global positioning and local positioning in their studies.

Our results indicate that, when a brand wants to position itself as global, segmentation based on consumer characteristics is necessary, as well as a different approach depending on the product category. Brand managers wanting to evoke perceptions of brand globalness or localness should emphasize global availability and reach or local relevance through the advertising copy, as this is the strongest determinant of perceived brand globalness. This result holds regardless of the product category and the consumer culture segment. Globalizing or localizing the brand logo will have little impact. Furthermore, brand managers targeting global-minded consumers, especially with a high-involvement product, are advised to also globally position the spokesperson. When targeting local-minded consumers, brand managers should consider localizing the brand name, as this relatively strongly influences perceived brand globalness among local-minded consumers, and prior research has indicated that these consumers tend to prefer a local brand.

\section{Limitations and suggestions for further research}

The present study has a number of limitations that provide opportunities for further research. First, the Netherlands is a developed country with a high level of foreign trade, a large immigrant population and a high openness to other cultures (Nijssen and Douglas, 2011). Possibly, the differences between local and global positioning would be different or more outspoken in, for example, more ethnocentric or more traditional societies (Steenkamp and de Jong, 2010) and developing countries (Alden et al., 1999). Even though we identified a "local" and "global" segment within the Netherlands, it is likely that the "local" consumer culture is still relatively global-minded. Therefore, future research should try and replicate these findings in different countries with different cultural backgrounds and degrees of economic development.

Second, chocolate is a rather hedonic product, while computers are more utilitarian (Khan et al., 2005), which can create a confound. We attributed the fact that for computers, consumers seem to especially weigh the brand name, to the fact that this verbal cue is more central. However, it could also be due to the fact that consumers would pay more attention to "rational" verbal cues 
for utilitarian products. While chocolate has typically been found to be a "low involvement" product (Dens and De Pelsmacker, 2010), it scored moderately on involvement in the sample of the present study. Future research should disentangle the effects of involvement and buying motivation, and consider a greater spread in involvement. As mentioned, our finding that the differences between local and global consumers are more outspoken for high involvement than for low-involvement products, seems to contradict prior research. Future research should try and explain how and why this contradiction could occur.

Our findings with respect to perceived brand globalness formation across the two consumer culture positioning segments studied, suggest different mechanisms for the two segments. While these results may provide tentative guidelines for academics and practitioners, the analyses do not explain why these differences occur. This is definitely a question that merits further research.

Further, we used printed ads in the present study. The results could differ when audio (visual) advertising (i.e. radio and TV) or interactive media (e.g. the web) are used. Research indicates that advertisements are processed differently in different media (Lien, 2001), which could impact the results. Using more interactive media would allow for the manipulation of story themes, a factor that is currently neglected. In addition, the use of music, for example, or spoken language, could also impact the relative importance of the cues under study (by decreasing, for example, the importance of advertising copy).

\section{References}

Aaker, J. and Maheswaran, D. (1997), "The effect of cultural orientation on persuasion", Journal of Consumer Research, Vol. 24 No. 3, pp. 315-328.

Ahmed, Z.U., Johnson, J.P., Yang, X., Fatt, C.K., Teng, H.S. and Boon, L.M. (2004), "Does country of origin matter for low-involvement products?", International Marketing Review, Vol. 21 No. 1, pp. 102-120.

Akaka, M.A. and Alden, D.L. (2010), "Global brand positioning and perceptions: international advertising and global consumer culture", International Journal of Advertising, Vol. 29 No. 1, pp. $37-56$.

Akram, A., Merunka, D. and Akram, M.S. (2011), "Perceived brand globalness in emerging markets and the moderating role of consumer ethnocentrism", International Journal of Emerging Markets, Vol. 6 No. 4, pp. 291-303.

Alden, D.L., Steenkamp, J.-B.E.M. and Batra, R. (1999), "Brand positioning through advertising in Asia, North America, and Europe: the role of global consumer culture", Journal of Marketing, Vol. 63 No. 1, pp. 75-87.

622 Alden, D.L., Steenkamp, J.-B.E.M. and Batra, R. (2006), "Consumer attitudes toward 
marketplace globalization: structure, antecedents and consequences", International Journal of Research in Marketing, Vol. 23 No. 3, pp. 227-239.

Amos, C., Holmes, G. and Strutton, D. (2008), "Exploring the relationship between celebrity endorser effects and advertising effectiveness", International Journal of Advertising, Vol. 27 No. 2, pp. 209-234.

Areni, C.S. (2003), "The effects of structural and grammatical variables on persuasion: an elaboration likelihood model perspective”, Psychology \& Marketing, Vol. 20 No. 4, pp. 349-375.

Braun-LaTour, K.A. and LaTour, M.S. (2004), “Assessing the long-term impact of a consistent advertising campaign on consumer memory”, Journal of Advertising, Vol. 33 No. 2, pp. 49-61.

Briley, D.A. and Aaker, J. (2006), "When does culture matter? Effects of personal knowledge on the correction of culture-based judgements", Journal of Marketing Research, Vol. 43 No. 3, pp. 395-408.

Bruning, E.R. (1997), "Country of origin, national loyalty and product choice: the case of international air travel”, International Marketing Review, Vol. 14 No. 1, pp. 59-74.

Cacioppo, J.T. and Petty, R.E. (1984), "The elaboration likelihood model of persuasion", Advances in Consumer Research, Vol. 11 No. 1, pp. 673-675.

Campbell, M.C. and Keller, K.L. (2003), "Brand familiarity and advertising repetition effects", Journal of Consumer Research, Vol. 30 No. 2, pp. 292-301.

Carrus, G., Nenci, A.M. and Caddeo, P. (2009), "The role of ethnic identity and perceived ethnic norms in the purchase of ethnical food products", Appetite, Vol. 52 No. 1, pp. 65-71.

Chaiken, S. (1980), "Heuristic versus systematic information processing and the use of source versus message cues in persuasion", Journal of Personality and Social Psychology, Vol. 39 No. 5, pp. 752-766.

Cleveland, M., Laroche, M. and Hallab, R. (2013), "Globalization, culture, religion, and values: comparing consumption patterns of Lebanese Muslims and Christians”, Journal of Business Research, Vol. 66 No. 8, pp. 958-967.

d'Astous, A. and Ahmed, S.A. (1999), "The importance of country images in the formation of consumer product perceptions”, International Marketing Review, Vol. 16 No. 2, pp. 108-126. 
De Mooij, M. and Hofstede, G. (2010), “The Hofstede model: applications to global branding and advertising strategy and research", International Journal of Advertising, Vol. 29 No. 1, pp. 85110.

Dens, N. and De Pelsmacker, P. (2010), "How advertising strategy affects brand and USP recall for new brands and extensions", International Journal of Advertising, Vol. 29 No. 2, pp. 165-194.

Diamantopoulos, A., Schlegelmilch, B.B. and Du Preez, J.P. (1995), "Lessons for pan-european marketing? The role of consumer preferences in fine-tuning the product-market fit", International Marketing Review, Vol. 12 No. 2, pp. 38-52.

Dimofte, C.V., Johansson, J.K. and Bagozzi, R.P. (2010), "Global brands in the United States: how consumer ethnicity mediates the global brand effect", Journal of International Marketing, Vol. 18 No. 3, pp. 81-106.

Dimofte, C.V., Johansson, J.K. and Ronkainen, I.A. (2008), "Cognitive and affective reactions of US consumers to global brands", Journal of International Marketing, Vol. 16 No. 4, pp. 113-135.

Dogerlioglu-Demir, K. and Tansuhaj, P. (2011), "Global vs local brand perceptions among thais and turks", Asia Pacific Journal of Marketing and Logistics, Vol. 23 No. 5, pp. 667-683.

Ettenson, R. (1993), "Brand name and country of origin effects in the emerging market economies of Russia, Poland and Hungary", International Marketing Review, Vol. 10 No. 5, pp. 14-36.

Fiske, S.T. and Pavelchak, M.A. (1986), "Category-based versus piecemeal-based affective responses: developments in schema-triggered affect", in Sorrentino, R.M. and Higgins, E.T. (Eds), The Handbook of Motivation and Cognition, Volume 1: Foundations of Social Behavior, Guilford, New York, NY, pp. 167-203.

Gammoh, B.S., Koh, A.C. and Okoroafo, S.C. (2011), "Consumer culture brand positioning strategies: an experimental investigation", Journal of Product \& Brand Management, Vol. 20 No. 1,pp. 48-57.

Garretson, J.A. and Burton, S. (2005), "The role of spokescharacters as advertisement and package cues in integrated marketing communications", Journal of Marketing, Vol. 69 No. 4, pp. 118-132.

Green, P.E. and Srinivasan, V. (1990), "Conjoint analysis in marketing: new developments with implications for research and practice”, Journal of Marketing, Vol. 54 No. 4, pp. 3-19.

Hair, J., Black, W., Babin, B., Anderson, R. and Tatham, R. (2006), Multivariate Data Analysis, Pearson International Edition, NJ.

Hannerz, U. (1990), “Cosmopolitans and locals in world culture”, Global culture: Nationalism, 
Globalization and Modernity, Vol. 7 No. 2, pp. 237-251.

Harris, G. and Attour, S. (2003), “The international advertising practices of multinational companies: a content analysis study", European Journal of Marketing, Vol. 37 Nos 1/2, pp. 154168.

Holt, D.B., Quelch, J.A. and Taylor, E.L. (2004), "How global brands compete”, Harvard Business Review, Vol. 82 No. 9, pp. 68-75.

Holton, R. (2000), "Globalization's cultural consequences", The Annals of the American Academy of Political and Social Science, Vol. 570 No. 1, pp. 140-152.

Johansson, J.K. and Ronkainen, I.A. (2005), “The esteem of global brands", Journal of Brand Management, Vol. 12 No. 5, pp. 339-354.

Kates, S.M. and Goh, C. (2003), "Brand morphing: implication for advertising theory and practice", Journal of Advertising, Vol. 32 No. 1, pp. 59-68.

Khan, U., Dhar, R. and Wertenbroch, K. (2005), "A behavioral decision theory perspective on hedonic and utilitarian choice", in Ratneshwar, S. and Mick, D.G. (Eds), Inside Consumption: Frontiers of Research on Consumer Motives, Goals, and Desires, Routledge, London, pp. 144165.

Krishna, A. and Ahluwalia, R. (2008), "Language choice in advertising to bilinguals: asymmetric effects for multinationals versus local firms", Journal of Consumer Research, Vol. 35 No. 4, pp. 692-705.

Kumar, A., Lee, H.-J. and Kim, Y.-K. (2009), "Indian consumers' purchase intention toward a United States versus local brand", Journal of Business Research, Vol. 62 No. 5, pp. 521-527.

Liang, B., Runyan, R.C. and Fu, W. (2011), "The effect of culture on the context of ad pictures and ad persuasion: the role of context-dependent and context-independent thinking", International Marketing Review, Vol. 28 No. 4, pp. 412-434.

Lien, N.-H. (2001), "Elaboration likelihood model in consumer research: a review", Proceedings of the National Science Council, Vol. 11 No. 4, pp. 301-310.

Miniard, P.W., Bhatla, S., Lord, K.R. and Dickson, P.R. (1991), "Picture-based persuasion processes and the moderating role of involvement", Journal of Consumer Research, Vol. 18 No. 1, pp. 92-107.

Nelson, M.R. and Paek, H.J. (2007), “A content analysis of advertising in a global magazine across seven countries: implications for global advertising strategies", International Marketing Review, Vol. 24 No. 1, pp. 64-86. 
Nijssen, E.J. and Douglas, S.P. (2011), “Consumer world-mindedness and attitudes toward product positioning in advertising: an examination of global versus foreign versus local positioning”, Journal of International Marketing, Vol. 19 No. 3, pp. 113-133.

Noriega, J. and Blair, E. (2008), "Advertising to bilinguals: does the language of advertising influence the nature of thoughts?”, Journal of Marketing, Vol. 72 No. 5, pp. 69-83.

Okazaki, S., Mueller, B. and Taylor, C.R. (2010), "Global consumer culture positioning: testing perceptions of soft-sell and hard-sell advertising appeals between us and Japanese consumers", Journal of International Marketing, Vol. 18 No. 2, pp. 20-34.

Özsomer, A. (2012), “The interplay between global and local brands: a closer look at perceived brand globalness and local iconness", Journal of International Marketing, Vol. 20 No. 2, pp. 7295.

Özsomer, A. and Altaras, S. (2008), "Global brand purchase likelihood: a critical synthesis and an integrated conceptual framework", Journal of International Marketing, Vol. 16 No. 4, pp. 128.

Özsomer, A., Batra, R., Chattopadhyay, A. and ter Hofstede, F. (2012), “A global brand management roadmap", International Journal of Research in Marketing, Vol. 29 No. 1, pp. 1-4.

Petty, R.E. and Briñol, P. (2008), "Persuasion: from single to multiple to metacognitive processes", Perspectives on Psychological Science, Vol. 3 No. 2, pp. 137-147.

Petty, R.E. and Cacioppo, J.T. (1986), Communication and Persuasion: Central and Peripheral Routes to Attitude Change, Springer-Verlag, New York, NY.

Petty, R.E., Cacioppo, J.T. and Goldman, R. (1981), "Personal involvement as a determinant of argument-based persuasion”, Journal of Personality and Social Psychology, Vol. 41 No. 5, pp. 847-855.

Rajabi, M. (2014), “Cross-cultural experiments on the effectiveness of advertising adaptation”, University of Antwerp, Antwerp.

Roy, R. and Chau, R. (2011), "Consumer-based brand equity and status-seeking motivation for a global versus local brand”, Asia Pacific Journal of Marketing and Logistics, Vol. 23 No. 3, pp. 270-284. 
Shimp, T.A. and Sharma, S. (1987), "Consumer ethnocentrism: construction and validation of the CETSCALE”, Journal of Marketing Research, Vol. 24 No. 3, pp. 280-289.

Sichtmann, C. and Diamantopoulos, A. (2013), "The impact of perceived brand globalness, brand origin image, and brand origin - extension fit on brand extension success", Journal of the Academy of Marketing Science, Vol. 41 No. 5, pp. 1-19.

Sinclair, J. and Wilken, R. (2009), "Strategic regionalization in marketing campaigns: beyond the standardization/glocalization debate", Continuum: Journal of Media \& Cultural Studies, Vol. 23 No. 2, pp. 147-157.

Steenkamp, J.-B.E.M. (2013), "How global brands create firm value: the 4V model", International Marketing Review, Vol. 31 No. 1, pp. 5-29.

Steenkamp, J.-B.E.M. and de Jong, M.G. (2010), "A global investigation into the constellation of consumer attitudes toward global and local products", Journal of Marketing, Vol. 74 No. 6, pp. $18-40$.

Steenkamp, J.-B.E.M., Batra, R. and Alden, D.L. (2003), "How perceived brand globalness creates brand value", Journal of International Business Studies, Vol. 33 No. 1, pp. 35-47.

Strizhakova, Y., Coulter, R.A. and Price, L.L. (2008), "Branded products as a passport to global citizenship: perspectives from developed and developing countries", Journal of International Marketing, Vol. 16 No. 4, pp. 57-85.

Swoboda, B., Pennemann, K. and Tauble, M. (2012), "The effects of perceived brand globalness and perceived brand localness in China: empirical evidence on Western, Asian, and domestic retailers", Journal of International Marketing, Vol. 20 No. 4, pp. 72-95.

Till, B.D. and Busler, M. (2000), "The match-up hypothesis: physical attractiveness, expertise and the role of fit on brand attitude, purchase intent and brand beliefs", Journal of Advertising, Vol. 29 No. 3, pp. 1-13.

Yin, J. (1999), "International advertising strategies in China: a worldwide surey of foreign advertisers", Journal of Advertising Research, Vol. 39 No. 6, pp. 25-35.

Zhang, Y. and Khare, A. (2009), "The impact of accessible identities on the evaluation of global versus local products", Journal of Consumer Research, Vol. 36 No. 3, pp. 524-537.

Zhou, N. and Belk, R.W. (2004), "Chinese consumer readings of global and local advertising appeals", Journal of Advertising, Vol. 33 No. 3, pp. 63-76.

Zou, S. and Volz, Y.Z. (2010), "An integrated theory of global advertising: an application of the gms theory", International Journal of Advertising, Vol. 29 No. 1, pp. 57-84. 


\section{About the authors}

Sarah De Meulenaer (Master Degree Commercial Engineer, Solvay Business School) is a Researcher and PhD Candidate at the University of Antwerp, Faculty of Applied Economics, Marketing Department. Her research focusses upon global marketing and branding strategies and cross-cultural differences in consumer responses to advertising. She has published in Journal of Advertising and serves as a reviewer for a number of journals. She has also presented some of her work at the European Marketing Academy Conference and International Conference on Research in Advertising. Sarah De Meulenaer is the corresponding author and can be contacted at: sarah.demeulenaer@uantwerpen.be

Professor Nathalie Dens ( $\mathrm{PhD}$, University of Antwerp) is an Associate Professor of Marketing at the University of Antwerp, Faculty of Applied Economics, Marketing Department and at Antwerp Management School. Her research focusses on advertising effectiveness for different marketing communication formats and branding strategies. She has published in international peer-reviewed journals such as Accident Analysis \& Prevention, Health Communication, International Journal of Advertising, International Journal of Electronic Commerce Research, Journal of Advertising, Journal of Business Research, Journal of Interactive Marketing, Marketing Letters, and Sex Roles: A Journal of Research. She serves as ad hoc reviewer for a number of journals and is a member of the editorial board of the International Journal of Advertising and Journal of Business Research.

Patrick De Pelsmacker ( $\mathrm{PhD}$, Ghent University) is a Professor of Marketing at the University of Antwerp, Faculty of Applied Economics, Marketing Department and at Ghent University, Faculty of Economics and Business Administration, Marketing Department. His research interests include advertising effectiveness, advertising in new media, consumer behavior, branding and ethical marketing. His publications have appeared in, amongst others: International Journal of Research in Marketing, Journal of Advertising, International Journal of Advertising, Journal of Interactive Marketing, Psychology \& Marketing, Marketing Letters, Journal of Business Research, Journal of Business Ethics, Journal of Consumer Affairs, Cyberpsychology \& Behavior, Accident Analysis \& Prevention, Health Communication and Journal of Health Communication. He is currently an Associate Editor of Journal of Advertising and Journal of Marketing Communications, and he is also on the Editorial Board of International Journal of Advertising and Journal of Public Policy and Marketing. 